\title{
THE ROLE OF HEALTH REPRODUCTION INFORMATION CENTER IN IMPROVING PRE-MARITAL SEX BEHAVIOR AMONG ADOLESCENTS IN BIMA, WEST NUSA TENGGARA
}

\author{
Mulya Tarmidi'), Argyo Demartoto²), Eti Poncorini Pamungkasari3) \\ 1)Masters Program in Public Health, Universitas Sebelas Maret \\ ${ }^{2)}$ Faculty of Social and Political Sciences, Universitas Sebelas Maret \\ 3)Faculty of Medicine, Universitas Sebelas Maret
}

\begin{abstract}
Background: Adolescent sexual and reproductive health is a major public health concern. A number of authors and organizations report that many adolescents world over are sexually active, and in some regions, as many as half are married. Literature shows that there is a need for improved reproductive health services aimed at adolescents throughout the world. This study aimed to investigate the role of health reproduction information center in improving pre-marital sex behavior among adolescents in Bima, West Nusa Tenggara.

Subjects and Method: This was a cross-sectional study conducted in Bima, West Nusa Tenggara, from April to June 2018. A sample of 200 senior high school students was selected by proportional stratified random sampling. The dependent variable was pre-marital sex behavior. The independent variables were health information center (PIK-KRR), intention, perceived behaviour control (PBC), and media exposure. The data were collected by questionnaire and analyzed by a multiple logistic regression run on Stata 13.

Results: Health information center had a positive effect on healthy pre-marital sex behaviour, but it was statistically non-significant $(b=1.64 ; 95 \% \mathrm{CI}=0.78$ to 3.44; $\mathrm{p}=0.188)$. Healthy pre-marital sex behavior increased with stronger intention $(b=17.18 ; 95 \% \mathrm{CI}=7.98$ to $36.97 ; \mathrm{p}<0.001), \mathrm{PBC}(\mathrm{b}=2.54 ; 95 \% \mathrm{CI}=1.19$ to $4.24 ; \mathrm{p}=0.016)$, and positive social media information exposure $(\mathrm{b}=2.01 ; 95 \%$ $\mathrm{CI}=0.95$ to $4.24 ; \mathrm{p}=0.068$ ).

Conclusion: The existing health information center in Bima, East Nusa Tenggara, is seemingly ineffective. It has a positive effect on healthy pre-marital sex behavior, but it is statistically non-significant. Healthy pre-marital sex behavior increases with stronger intention, $\mathrm{PBC}$, and positive social media information exposure.
\end{abstract}

Keywords: healthy pre-marital sex behavior, health information center, social media information exposure

\section{Correspondence:}

Mulya Tarmidi. Masters Program in Public Health, Universitas Sebelas Maret, Jl. Ir. Sutami No.36 A, Surakarta, Central Java. Email: bluedaeng@gmail.com.

Mobile: +6285238609735

The 4th International Conference on Public Health Best Western Premier Hotel, Solo, Indonesia, August 29-30, 2018 | 162 https://doi.org/10.26911/theicph.2018.02.43 